\title{
First Impressions: Anglo Travelers and the Origins of El Paso, Texas, 1846-1852
}

Mark Cioc-Ortega

Department of History, University of California Santa Cruz

Follow this and additional works at: https://scholarworks.sfasu.edu/ita

Part of the American Material Culture Commons, Archaeological Anthropology Commons, Environmental Studies Commons, Other American Studies Commons, Other Arts and Humanities Commons, Other History of Art, Architecture, and Archaeology Commons, and the United States History Commons

Tell us how this article helped you.

This Article is brought to you for free and open access by the Center for Regional Heritage Research at SFA ScholarWorks. It has been accepted for inclusion in Index of Texas Archaeology: Open Access Gray Literature from the Lone Star State by an authorized editor of SFA ScholarWorks. For more information, please contact cdsscholarworks@sfasu.edu. 


\section{First Impressions: Anglo Travelers and the Origins of El Paso, Texas, 1846-1852}

\section{Licensing Statement}

Reproduction, posting, transmission, or other distribution or use of the Journal volume, individual article or any portion of the material therein, in any medium, is permitted strictly for personal, non-commercial purposes via a personal-use exemption under a Creative Commons license granted by JTAH.org, Inc. This license exemption requires, as a condition of its granted permission, proper credit be attributed to JTAH.org as copyright holder (e.g., Journal of Texas Archeology and History.org @ 2015). No part of this publication may be reproduced, posted, transmitted, or otherwise utilized or distributed in any form by any means or method for commercial purposes without the express written consent of the Publisher.

Inquiries should be addressed to JTAH Publisher, Suite 307, Box 361, 5114 Balcones Woods Drive, Austin, Texas, 78759.

The Journal of Texas Archeology and History.org is an organization dedicated to furthering research, education and public outreach in the fields of archeology and history concerning Texas and its bordering states of Louisiana, Arkansas, Oklahoma, New Mexico and Northern Mexico; a region we call the "Texas Borderlands." The J.T.A.H. is collaborating with the Index of Texas Archaeology and S.F.A.S.U. to distribute their publication library to the general public via free and open-access channels. Visit www.JTAH.org to submit an article. 


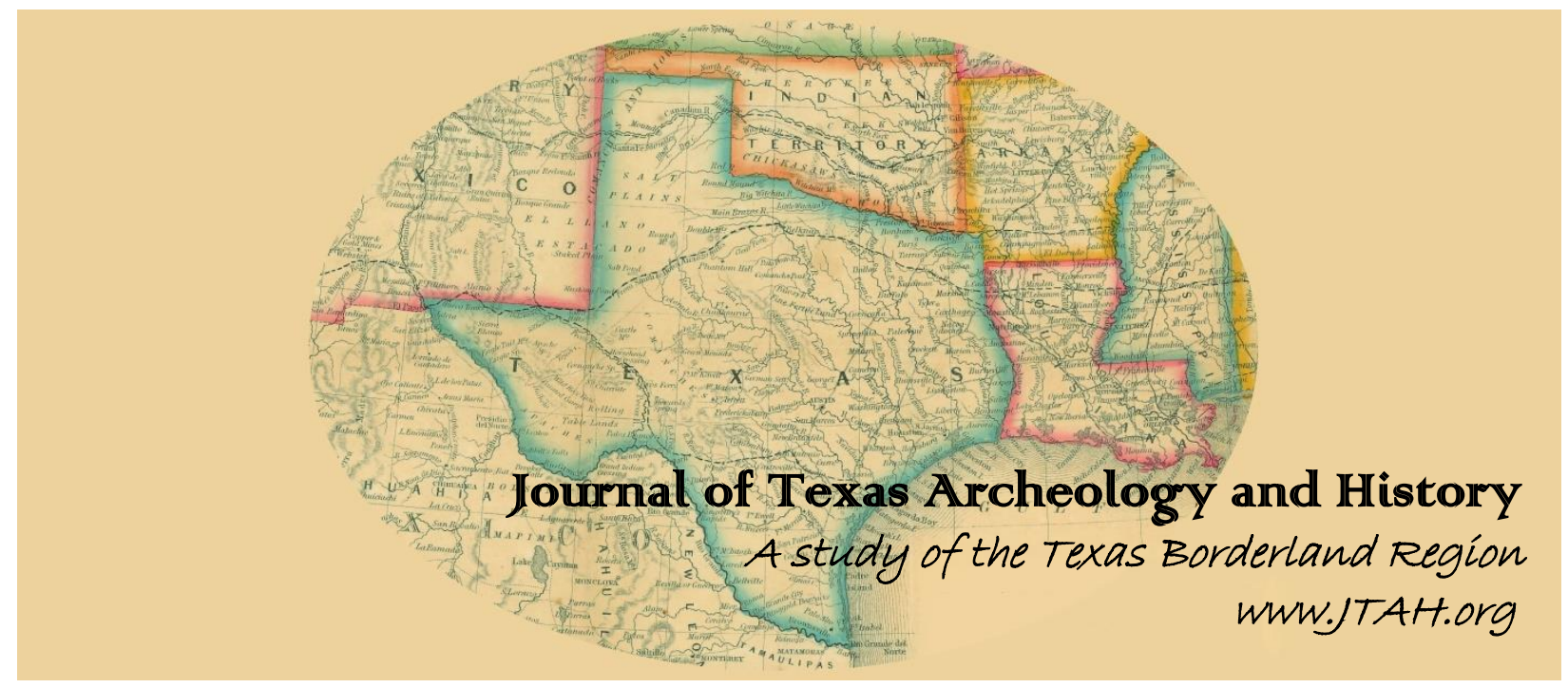

\section{Article Title: FIRST IMPRESSIONS: ANGLO TRAVELERS AND THE ORIGINS OF EL PASO, TEXAS, 1846-1852}

Author(s): $\quad$ Mark Cioc-Ortega

Original Source: J.T.A.H. Volume 2(2015), Article 4, pp. 58 - 72; online 18 June 2015

Recommended Citation: Cioc-Ortega, Mark; "First Impressions: Anglo Travelers and the Origins of E1 Paso, Texas, 1846-1852", (2015), Journal of Texas Archeology and History Volume 2 (2015), pp. 58 72.

Copyright $(\odot 2015$ by Journal of Texas Archeology and History.org, Inc. All rights reserved. Online/Digital publication: ISSN 2334-1874

The online, digital and print versions of the publication "Journal of Texas Archeology and History" are published by Journal of Texas Archeology and History.org, Inc., a Texas nonprofit IRC Section 501(c)(3) corporation.

Reproduction, posting, transmission, or other distribution or use of the Journal volume, individual article or any portion of the material therein, in any medium, is permitted strictly for personal, non-commercial purposes via a personal-use exemption under a Creative Commons license granted by JTAH.org, Inc. This license exemption requires, as a condition of its granted permission, proper credit be attributed to JTAH.org as copyright holder (e.g., Journal of Texas Archeology and History.org (C) 2015). No part of this publication may be reproduced, posted, transmitted, or otherwise utilized or distributed in any form by any means or method for commercial purposes without the express written consent of the Publisher. Inquiries should be addressed to JTAH Publisher, Suite 307, Box 361, 5114 Balcones Woods Drive, Austin, Texas, 78759.

The Journal of Texas Archeology and History.org is an organization dedicated to furthering research, education and public outreach in the fields of archeology and history concerning Texas and its bordering states of Louisiana, Arkansas, Oklahoma, New Mexico and Northern Mexico; a region we call the "Texas Borderlands." The J.T.A.H. is collaborating with the Index of Texas Archaeology and S.F.A.S.U. to distribute their publication library to the general public via free and open-access channels. Visit www.JTAH.org to submit an article. 


\title{
FIRST IMPRESSIONS: ANGLO TRAVELERS AND THE ORIGINS OF EL PASO, TEXAS, 1846-1852
}

\author{
Mark Cioc-Ortega
}

\begin{abstract}
El Paso del Norte was a thriving agricultural region on the Santa Fe-Chihuahua trail when the U.S.-Mexico War (1846-1848) and the 1849 gold rush turned it into a border town on the southern route to California. The diaries and letters of the Anglo-American soldiers, engineers, and gold seekers who passed through the area in the 1840s and 1850s document the emergence of a new political and economic landscape that helped define the pattern of Anglo-Mexican relations in the new town of El Paso, Texas (across the Rio Grande from El Paso del Norte), well into the next century.
\end{abstract}

Key Words: El Paso, El Paso del Norte, Ciudad Juárez, argonaut, gold rush, Santa Fe-Chihuahua trail, Upper Emigrant trail, Lower Military trail, Ponce Ranch, Coons' Ranch

\section{INTRODUCTION}

Around 40,000 "argonauts" (gold seekers) traveled to California on the Oregon trail during the 1849 gold rush, and an additional 20,000 or so took more southerly trails. The southern routes included the wellestablished Santa Fe-Chihuahua trail, which linked Missouri to New Mexico; and the newly charted Upper Emigrant and Lower Military feeder trails, which stretched across Texas from Austin and San Antonio to El Paso del Norte (modern-day Ciudad Juárez, Mexico). As Patricia Etter (1998:34) wrote in To California on the Southern Route 1849, these trails funneled around 7,000 gold seekers (over one-third of the southern travelers) through the El Paso del Norte region: "Most folks on the so-called feeder trails got along fairly well," Etter noted. "There were hardly any skirmishes with Indians (more individuals were hurt or killed with their own guns); cholera disappeared as they moved inland; water, wood, and feed for animals were generally available; the animals were not yet trail worn; and they could all refresh and recruit in numerous New Mexican villages. But there would be hard times ahead as they entered the western desert, where water was the most prized possession."

El Paso del Norte was an important stopping point on the southern routes: it was a major Mexican entrepôt on the Santa Fe-Chihuahua trail and also the western terminal of the Texas feeder trails. A thriving agricultural town with many downstream villages (San Lorenzo, Senecú, Ysleta del Sur, Socorro, and San Elizario), it offered the argonauts one of their best opportunities to replenish supplies, repair wagons, and regain strength before facing the arid terrain ahead. There was also a swath of land north of El Paso del Norte,

\footnotetext{
JOURNAL OF TEXAS ARCHEOLOGY AND HISTORY

VOLUME 2:58-72

THE ONLINE PUBLICATION JOURNAL OF TEXAS ARCHEOLOGY AND HISTORY (ISSN 2334-1874)

IS PUBLISHED BY JOURNAL OF TEXAS ARCHEOLOGY AND HISTORY.ORG.

COPYRIGHT (C) 2015 JOURNAL OF TEXAS ARCHEOLOGY AND HistORY.ORG. ALL RIGHTS RESERVED.
} 
known as Ponce's Ranch, which was located on the American side of the U.S.-Mexico border; over 500 acres in size, it was large enough to serve as an Anglo "suburb" of El Paso del Norte until it became the town of El Paso, Texas, during the course of the 1850s.

Many argonauts kept diaries and wrote letters as they journeyed toward San Diego and Los Angeles, and a few also wrote reminiscences about their trail-time experiences many years later. When one adds other related accounts and records - by soldiers and topographical engineers who came through El Paso del Norte during the U.S.-Mexico War (1846-1848), by member of the International Boundary Commission (18491856), and by the traders who regularly plied the Sante Fe-Chihuahua trail-the number of these eye witness accounts swells even more. Taken together, they provide an illuminating snapshot of the El Paso del Norte region in the late 1840 s and early 1850 s as seen from the perspective of the Anglo-American travelers.

Some of these diarists and letter writers were quite loquacious, while others were tight-lipped. Some were full of energy and anticipation, while others were exhausted and despondent. Most offered positive descriptions of the region, while some expressed disappointed with what they saw. A few left the area as fast as their mules and horses could take them, while others stayed on permanently or returned later. Despite the variations, some common narrative themes can be discerned, which can be grouped loosely under the following rubrics: descriptions of the local geography, climate, and agriculture; impressions of the Mexican villages and inhabitants; and reflections on the future of the region now that the Treaty of Guadalupe Hidalgo (1848) had turned the El Paso del Norte region into a borderland.

That they came with fresh eyes can scarcely be doubted: few had ever heard of the region or been exposed to Mexican culture before they arrived. However, they were not blank slates: they filtered what they saw through a pre-existing lens of expectations and prejudices in ways that greatly colored their perceptions and descriptions. All wrote in English and identified themselves to one extent or another as Anglo-Americans (or simply Americans), a catch-all racial designation of that era for whites of Euro-American descent who identified with the political and cultural norms of the United States. All but two of the writers were men. Only a handful donned the scientific mantle of "objective observer" or the anthropologist's pose of "neutral narrator." And those who did - such as John Bartlett and William Emory-were mostly working for the federal government or writing travelogues for posterity, or both. The vast majority wrote for themselves or their immediate families, not for publication, and they tended to give vent to their class, race, and gender biases without restraint. Taken together, they document the birth of an American political landscape, racialized and gendered according to U.S. norms, that helped establish the pattern of Anglo-Mexican relations in the El Paso del Norte region for many decades to come.

Many historians have chronicled the emergence of Anglo settlements in the El Paso del Norte region during the second half of the $19^{\text {th }}$ century. They generally fall into one of two groups: those who view the new town of El Paso, Texas, as a tolerant bi-national community that offered a congenial blend of American and Mexican lifestyles; and those who view El Paso as a bifurcated community in which an Anglo overclass and a Mexican underclass interacted across a racial divide, often peaceably but sometimes not. The first group of historians typically begins with the 1840s and 1850s, a time when Anglo-American entrepreneurs - such as James Wiley Magoffin, Simeon Hart, and Hugh Stephenson-infused new commercial life into the region. These entrepreneurs entertained in grand style, forged friendships with upper-class Mexican men, and married well-bred Mexican women — creating a seamless web of Anglo-Mexican commercial relationships 
stretching from Santa Fe in the north to Chihuahua City in the south that fostered a tradition of bi-ethnic cooperation (Strickland 1963; Sonnichsen 1968; Timmons 1990). The second group tends to focus on the 1880s and beyond, when the railroads arrived and the city's population boomed. This was the time when Anglo-Americans came to fully dominate the region, with Anglo Protestants firmly in control of the political, social, and economic life of the region, even while the cultural and religious life remained largely Mexican and Catholic (García 1981; Ramirez 2000). This article strikes a middle ground: it argues that the gold seekers of the late 1840s and early 1850s provided a foreshadowing of the bifurcated community that would more fully emerge three decades later when the railroads opened up the region to extensive Anglo settlement.

\section{LANDSCAPES OF DEARTH, LANDSCAPES OF ABUNDANCE}

The diarists and letter writers were traveling westward, mostly from southern and borderline southern states such as Missouri, Tennessee, and Texas, but sometimes from as far away as the northeastern seaboard (where they would typically take a ship from New York to New Orleans or Galveston before joining one of the feeder trails). They were thus coming from wetter, greener, and cooler climes and their descriptions make clear that they were overwhelmed by the dry heat and stark aridity of west Texas and southern New Mexico. "The children of Israel while journeying to the promised land, with all their suffering for three hundred years, could hardly have endured what we did while traveling through that horrid valley of dry thorns," wrote the argonaut H.S. Brockway (1982:2-3), as his group passed through New Mexico's aptly named Jornada del Muerto ("the dead man's route") on the way to El Paso del Norte. "Fancy yourselves traveling under an almost vertical sun - the air full of dust, and the thermometer standing at 110 - and you will get a faint idea of our situation." Relief came a few days later when the group reached the water-rich Rio Grande, but the river gave Brockway little cause to rejoice: "Here we learned the wretched condition of a company who had left Texas about six weeks before us. They had been so near starvation as to be compelled to eat their mules and horses, and came in on foot, in parties of six or eight. They have not all been heard from yet, and probably never will be."

Brockway had a flair for the dramatic, but similar stories of adversity can be found in many of the diaries and letters. Travelers ran out of food and water. They lost track of the route and went round in circles. Their pack animals grew sick and died. They were attacked by Apaches. Even the soft-spoken Louisiana Strentzel (1983:265-266), one of only two female narrators among the argonauts (and by far the most thoughtful, practical, and even-handed of them all) warned her friends not to follow in her footsteps: "If you do come I advise you to come by water, it is far less expensive and you can come in half the time that you can by land. I cannot advise any family to come the overland route." Realizing that her friends would likely ignore her advice, she then proffered practical suggestions for weathering the heat and terrain:

prepare well for the journey and travel in small consolidated companies, say about ten wagons and twenty or twenty-five men, to each family I would say one light strong carriage for women and children to ride in (with two mules)...Put nothing in your wagon except provisions and clothing and such articles as are indespensibly [sic] necessary on the road. Bring vessels to haul about fifty gallons of water; india-rubber sacks are the best...We brought our own cow clear through. She has been worth thousands of dollars to us, yes, I may say millions, for she has been the means of preserving the lives of our children. 
One of her two children, the two-year old Louisa "Louie" Strentzel, would go on to become an accomplished pianist and the spouse of California naturalist John Muir.

Whether travelers took the Santa Fe-Chihuahua trail or one of the Texas feeder trails, they most likely arrived in the El Paso del Norte valley on the left bank (more often referred to as the north or east bank) of the Rio Grande, on a small curvature of land that had just passed into American hands. Not many of the travelers mentioned the only significant landmark on the north bank of the river, Ponce's Ranch. Established by Don Juan María Ponce de León in 1827, it was renamed Coons' Ranch (often misspelled Coon's) after Benjamin Franklin Coons purchased it in 1849, and it was renamed again Smith's Ranch after William "Uncle Billy" Smith took possession of it in 1853.

The Ponce-cum-Coons-cum-Smith ranch looms large in El Paso history because it later became the heart of the town's business district. But at the time it did not make much of an impression on the Anglo travelers. The usually loquacious George Gibson (1974:311-312), who traveled with Doniphan's army in 1846-1847, gave only a terse description: "Early in the afternoon we reached Ponce's Ranch on this side, and passing over a pretty bottom with rows of cottonwood and vineyards on each side, reached the ford and were soon across the river." Even after Coons built a trading post on a portion of the ranch and leased another portion to the U.S. Army as a military outpost, Anglo visitors remained largely indifferent to this burgeoning new settlement. The argonaut David Demarest, who wrote vivid and detailed descriptions in his diary of the downstream villages of Ysleta and Socorro (which he misnamed "Elleto" and "Sonora"), had little to say about Coons' Ranch when he came through in September 1849: "Moved up to Coon's - had to take to the hills as the Valley is full of water" (Demarest 1849-1850). Similarly, the vivacious Robert Eccleston (1950:150151), who also passed through in September 1849 en route to California, showed little curiosity about the site: "We passed Coon's Ranch, occupied by the government. We then passed through something resembling an Arcade-trees (cottonwood) about $4 \mathrm{ft}$. apart, shading it. It was very muddy \& part of the road was entirely under water."

It was the right bank (more often called the south or west bank) that interested Anglo travelers upon their arrival in the El Paso del Norte region. From Ponce's Ranch or anywhere else on the north side of the Rio Grande, they could behold the lush and verdant Mexican agricultural community of El Paso del Norte just across the river, beckoning like a siren's song. Josiah Gregg (1844:76), who came through in the early 1840s as a Santa Fe trader, set the literary tone for subsequent travelers in his description of the town:

The valley of El Paso is supposed to contain a population of about four thousand inhabitants, scattered over the western bottom of the Rio del Norte [Rio Grande] to the length of ten or twelve miles. These settlements are so thickly interspersed with vineyards, orchards, and cornfields, as to present more the appearance of a series of plantations than of a town: in fact, only a small portion at the head of the valley, where the plaza publica and parochial church are located, would seem to merit this title.

Marcellus Edwards (1936:245), a soldier in Doniphan's army, was even more enthralled:

El Paso appears to be the garden spot of Mexico. Nature has been more lavish with her care towards this place than any I've met with. The valley is thickly settled for ten miles 
below, with orchards and vineyards, so that each family has more fruit of every kind than it can consume...They raise apples, peaches, pears, etc., which they dry and preserve for winter. Each family has a supply of wine of their own manufacture, and being the pure juice of the grape, when rightly made, is of an excellent flavor, scarcely equaled by any wines in the world.

Friedrich Adolph Wislizenus, a doctor who accompanied Doniphan's army, was similarly impressed: "Stretched out along the river to the length of many miles, all the houses surrounded by gardens, orchards, and vineyards, and rich settlements, with cornfields, as far as the eye can trace the stream, lining its green bank - such a scenery will always be attractive; but to a traveler, who has passed over the lonesome plains and through the dreary Jornada del Muerto, it appears like an oasis in the desert" (Wislizenus 1848:40) (Figure 1). And William Emory, a topographical engineer and head of the International Boundary Commission, wrote in the 1850s: "The town of El Paso is itself but one extended vineyard in the hands of many proprietors...The grapes, peaches, figs, melons, and the fruits generally of this valley, are of very superior quality. There are two descriptions of grapes - one white, the other large and blue; both are very luscious, having no trace of the musky taste of American grapes, and in skilful [sic] hands make delicious wine and good brandy" (Emory 1857-1859:91).

None of the Anglo visitors were particularly good at guessing the size of El Paso del Norte's population - their estimates varied from 1000 to 10,000 - but they were remarkably consistent in their assessment of the local products and delicacies, which they devoured with gusto. The grapes, peaches, and onions received almost universal praise, as did the local wines and the "Pass whiskey" (a brandy distilled from local grapes). The quinces, figs, melons, and raisins were also generally well liked, while the pears and apples got mixed reviews. The prepared foods were highly praised, especially the tortillas and chili peppers, which the emigrants found to be both novel and tasty. Frank Edwards (1847:98), a soldier in Doniphan's army, was especially impressed by a "hot piece of baked pumpkin" that someone gave him, which he declared to be "far superior in flavor to those at home;" and it did not bother him a whit that the local "peons" laughed at him for his "unaristocratic relish for what is here grown only for the pigs and servants." William Henry Glasgow, meanwhile, loved the "peach pies... with onions in them," which he tasted while visiting Doña Ana, a small town upstream from El Paso del Norte (Glasgow and Glasgow 1993:102). And Thomas Eastland, a gold seeker who arrived at Ysleta (downstream from El Paso del Norte) in September 1849, could hardly believe his good fortune: "We have rented a room in the midst of a Vineyard, Fruit Trees \&C for \$3 per month," including the "run of the Ranche (we will eat Grapes enough to amount to twenty times that sum) and have our Mules \& Horses attended to and Grazed for 25 Cents a head per month" (Eastland 1939:120).

These assessments turned negative in the course of 1849, as El Paso del Norte's resources became depleted by thousands of visiting argonauts. However, the food and supply shortages lasted only briefly and the Americans were soon praising the food and accommodations once again. 


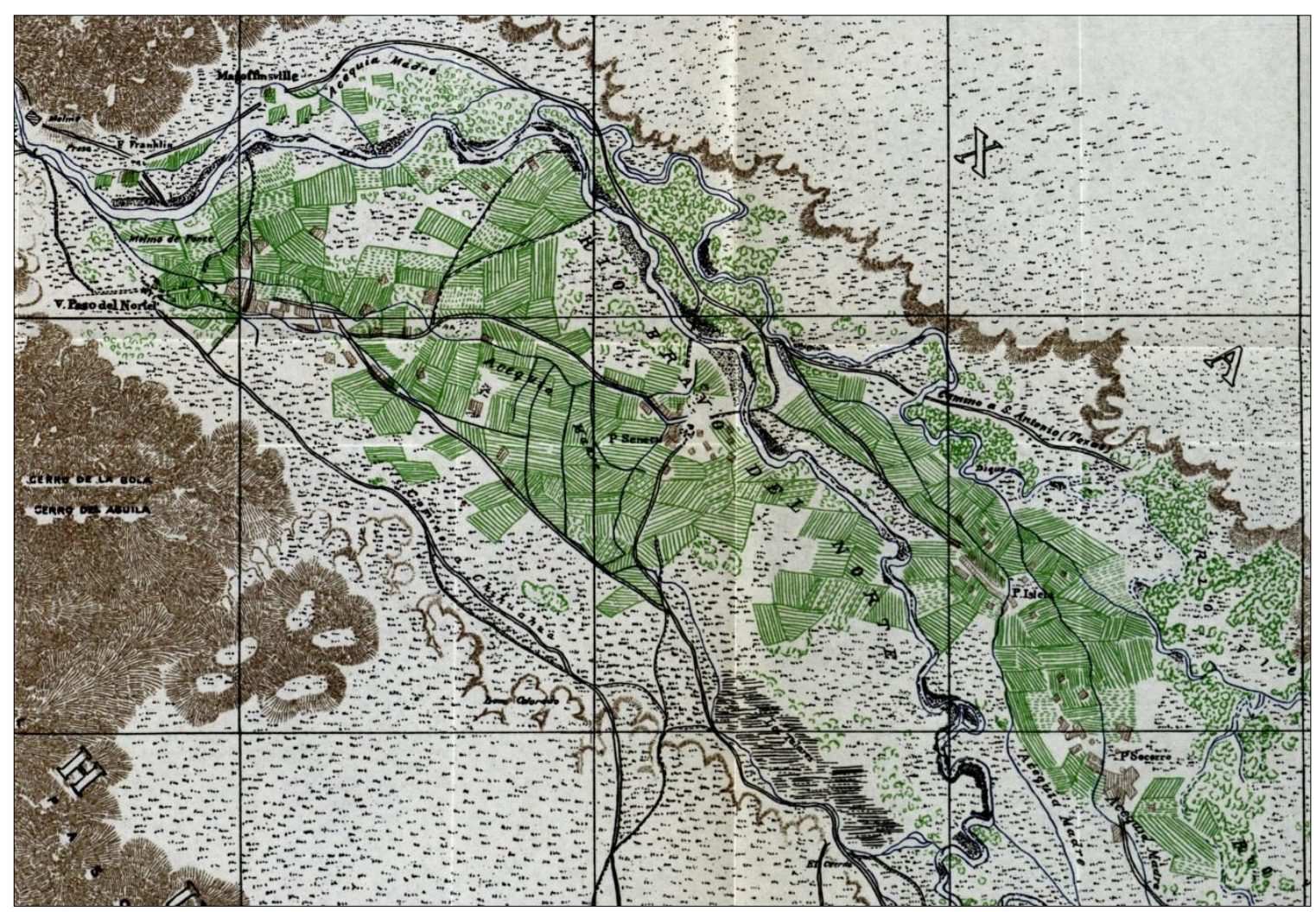

Figure 1. Close-up of the El Paso del Norte region ca. 1860s (Comisión Internacional de Límites entre Mexico y los Estados Unidos 1911). The most prominent settlements include "Paso del Norte," renamed Ciudad Juárez in 1888 to honor Benito Juárez; "Franklin," the oft-used name for the new El Paso, Texas, to avoid confusion with nearby Paso del Norte; and "Magoffinsville," James Magoffins' short-lived settlement and army post, later absorbed into El Paso. Nearly all of the orchards and vineyards were located on the Mexican side of the Rio Grande.

\section{PROFILING BY RACE AND GENDER}

Perhaps nothing offers a more tell-tale sign of things to come than Anglo reactions to the local inhabitants of the El Paso del Norte region. Only a handful of the diarists and letter writers even realized that they were passing through a multiethnic and multicultural region. Most tended to lump all the locals under the rubric of "Mexicans" (or the pejorative "greasers"), distinguishing among them solely along class lines, with the wealthier and more powerful inhabitants being spared most of the verbal barbs directed at the poor and unwashed.

There was, however, a striking difference between the way they wrote about women and men, with the women being almost universally praised and the men almost uniformly criticized. This is not altogether astonishing, when one keeps in mind that most of the soldiers and argonauts were single men in their 20s and 30s, who likely viewed the women as potential lovers. The argonaut Cornelius Cox, for one, found the women "kind, warm-hearted and generous to a Fault," but thought the men were ignorant, indolent, and cowardly (Cox 1849). After a brief excursion into El Paso del Norte, Robert Eccleston (another argonaut) was similarly moved to write: "There is one thing I can say favorable, \& that is that I saw three or four beautiful women in the place" (Eccleston 1950:152). In 1847, one of Doniphan's military commanders, John Hughes, 
worried that the abundance of "fair señoritas" would lead to desertions in his ranks, and his fears were well founded: when Major Isaac H. Duval visited El Paso del Norte in 1849, he came across no less than 25 veterans of the U.S.-Mexico War who had stayed behind when the rest of Doniphan's army pushed farther into the Mexican interior (Hughes 1997:140; Duval 1987:76-77). The argonaut Thomas Eastland (1939:127) was a rare dissenter: "The Señoritas of El Paso are a poor looking set-I have not observed even a passable face, compared with our American beauties - I have looked in vain for those 'dark liquid eyes,' 'long silken eye lashes,' and 'fawn like figures' some travellers talk of - no such things in these diggins [sic] - all poetry." But Eastland was writing a letter to his wife, which no doubt shaped his choice of words.

If Anglo travelers thought the women were naturally beautiful, they viewed the men as naturally lazy, indolent, uninventive, gamble-happy, and prone to thievery (even the local priests were not spared). "Wheat and corn are the only grains raised here and they do well even with the very bad management they get," declared David Demarest (Demarest 1849-1850). "We were very much surprised to see so large a town destitute of the common comforts of life," stated an anonymous traveler on June 4, 1849: "And this state of privation is in a region where every inducement is offered to the tiller of the soil, but such is the characteristic indolence of the Mexicans" (Anonymous 1977:269-70).

Similarly, John Murchison, who was to die in a rifle mishap a short time later, vented his spleen at the "miserable lazy perished out Mexicans who pretend to live in this region" (Lagrange Company 1849). The surgeon Samuel Woodhouse (2007:52), who passed through El Paso del Norte in 1851, echoed the same sentiment: "The soil on this side of the river is exceedingly rich and could be made a perfect garden. Nature does everything for them [the Mexicans], but they are exceedingly lazy." Meanwhile, Thomas Eastland outdid them with his shrill contempt and his staccato-like writing style:

A good and industrious American farmer, with a few Hands, could make a fortune here in a few years - the soil is rich, easily irrigated, and can be cultivated with great ease-land is very cheap, and many of the Mexicans are anxious to sell out - scarcely any Vegetables are raised - Cotton \& sugar can be grown successfully indeed any and every thing-The Inhabitants are very indolent, possess none, or very few implements of husbandry, indeed it seems that their Crops Grow without cultivation-Ploughs are unknown-a heavy unwieldy hoe is used instead-it is astonishing to walk through the fields, and see how luxuriant and healthy everything looks - the Grape Vines are filled with fruit, as well as the Peach, Apple, Pear \& Quince trees - the Corn is excellent, and the Grain unusualy [sic] full...Visited El Paso - it is a miserable place, nothing to eat for Man or Beast - the citizens lazy, mean \& thieving, I am greatly disappointed in this place, it has always been represented as an Eden - I am sure Old Adam would not have thought so, barring the fine Grapes \& other fruit (Eastland 1939:120-21).

Only a handful of the diarists were wholeheartedly positive about the locals. One of them was George Kendall, a survivor of the ill-fated Santa Fe expedition of 1841, who thought the locals were "more honest, industrious, cleanly, and better disposed towards foreigners than those of any town of equal size I passed through in my long journey" (Kendall 1935:35). Another exception was Benjamin Harris, who was enamored by the "one-storey adobe houses," the "novel costumes of males and females," the "divine and beautiful Spanish language," the enterprising spirit of the men, and the abundance of "fashionable ladies" 
(Harris 1960:151-152). Meanwhile, William Whiting was one of the few Anglos to recognize that San Elizario (downstream from El Paso del Norte) was not peopled by ethnic Mexicans but by "remnants of the old Indian tribes long since reduced by the Spaniards." They are "a frugal and peaceable race," he declared, and "there is far greater appearance of plenty and comfort here" than elsewhere in the valley (Whiting 1938:316).

While Whiting and a few others had positive things to say about the "tame" Native Americans, none had anything but contempt for the "wild" ones, especially the Apaches, who dominated the plains surrounding the Rio Grande. In fact, Apaches were the only group more reviled than Mexican men. The diarists made frequent reference to the difficulties that the Apaches caused them on their journey, mostly through the rustling of horses and cattle but also occasionally through kidnappings and deadly ambushes. Once again it was Thomas Eastland who best expressed these sentiments, by putting words into the mouths of the Apaches:

The neighboring tribes of Indians, particularly Apaches, are very troublesome, and swear eternal hostility, of course Uncle Sam must take his rod out of pickle, and teach them obedience-I understand that they bitterly complain at our Treaty stipulation with Mexico, to protect that Government from their Marauding incursions, and boldly ask 'What are we to do if we are to be deprived of that immemorial privilege of our race, to steal all the property we want from the Mexicans, and make of their Nation as many captives every year, as answer our purposes? We dont [sic] know how to work, we cant [sic] plough, and sow and reap as the white men, nor can we learn - our Men Women and Children, have been educated to live by stealing, and we will not submit to the Government of the U.S. in thus meddling with our institutions,'- so you see, nothing short of their entire subjection, will ensure security to either the Mexicans, or our own people on the Frontier...The Texas Rangers are alone fit for this kind of warfare, the Indians know them and fear them, and acknowledge no other superiors or equals (Eastland 1939:122).

\section{AMERICAN SUPERIORITY AND THE FUTURE OF THE EL PASO DEL NORTE REGION}

Given these attitudes, it is not surprising that many of the travelers felt that what was most needed was an infusion of manly men into the El Paso del Norte region, in the form of American soldiers, topographers, and immigrants. Indeed, the diaries and letters fairly burst with the trope of Manifest Destiny. "If this valley were cultivated by an energetic American population," wrote John Hughes to the War Department in 1847, "it would yield, perhaps, ten times the quantity of wine and fruits at present produced. Were the wholesome influences and protection of our republican institutions extended to the Rio del Norte [Rio Grande], an American population possessing American feelings and speaking the American language would soon spring up here. To facilitate the peopling of this valley by the Anglo-American race nothing would contribute so much as the opening of a communication between this rich valley and the Western States of our Union by a turnpike, railroad or some other thoroughfare which would afford a market for the fruits and wines of this river country" (Hughes 1997:142) (Figure 2). 


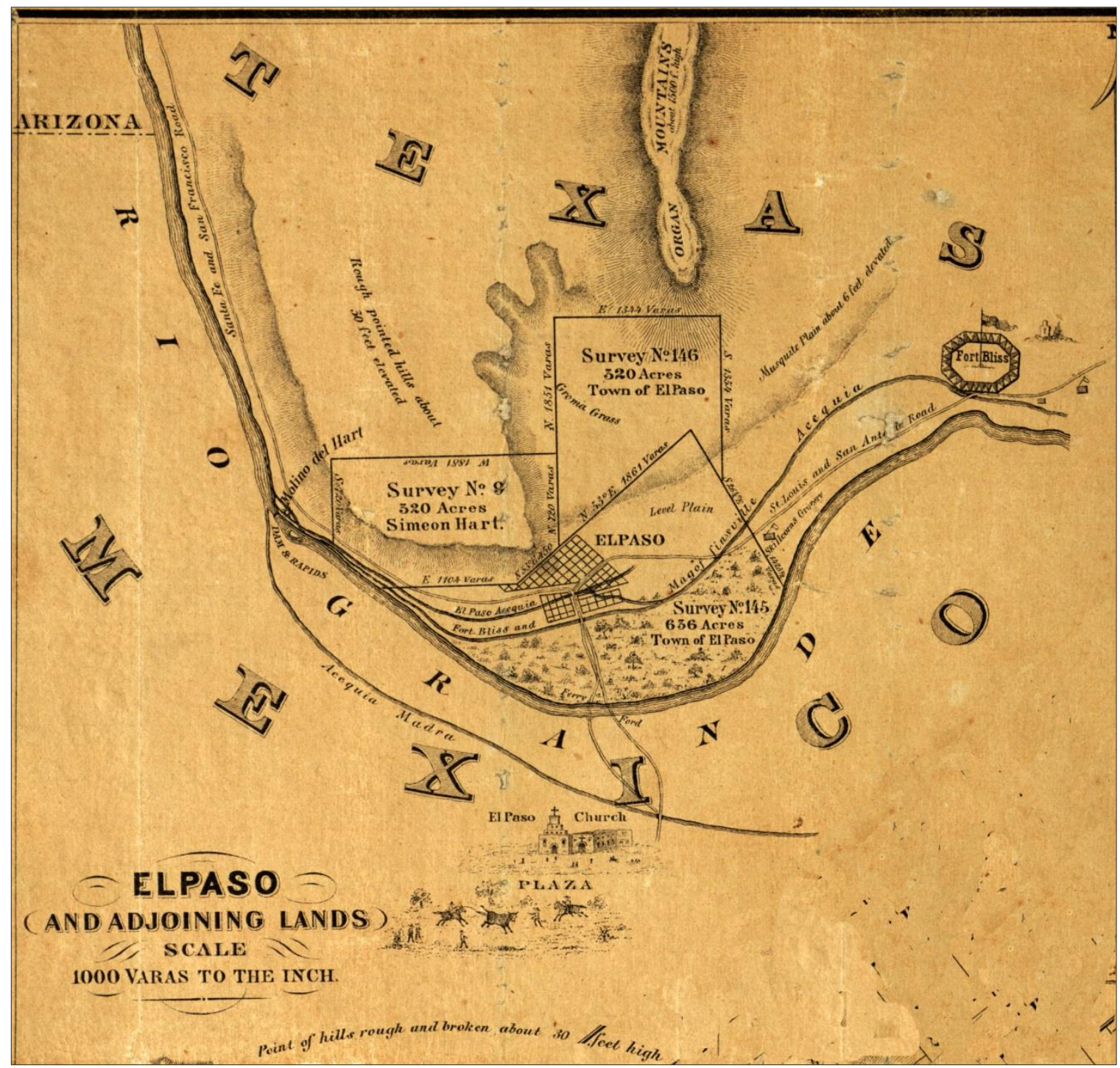

Figure 2. Close-up of Anson Mills, "Plat of El Paso" (1859) showing the new settlement of El Paso, Texas, on the American side of the Rio Grande (El Paso County Historical Society 1859). The gridded area is the heart of the Ponce Ranch and the future downtown El Paso. "Fort Bliss," shown on the right side, was located at Magoffinsville. The "El Paso Church" and "Plaza" near the bottom of the map show the location of El Paso del Norte (Ciudad Juárez).

Similarly, George Ruxton (1916) proclaimed: "Should this department [the river stretch between El Paso del Norte and New Mexico] fall into the hands of the Americans, it will soon become, a thriving settlement; for the hardy backwoodsman, with his axe on one shoulder and rifle on the other, will not be deterred by the savage, like the present pusillanimous owners of the soil, from turning it to account." And William Whiting, who was part of a military reconnaissance to find a route between East Texas and the El Paso del Norte region, expressed much the same sentiment: "In their system of agriculture nothing is seen to be admired but the irrigation, and that could be vastly improved by the introduction of American industry and ingenuity...Indolent and improvident, these people rarely raise more than sufficient for their own immediate wants" (Whiting 1938:301). 
Perhaps the diary of L. N. Weed most jarringly reveals the confusion of values that made it so difficult for the argonauts to fully appreciate the region for what it was, namely an extraordinary outpost of Hispanic civilization in the middle of the vast Sonora desert. Weed was an unabashed racist (his diary is chock full of references to skin color and ethnicity) who had traveled by sea from New York to Galveston in March 1849, where he had joined a large party that took the Upper Emigrant trail to California. "The Mexicans make much of Americans, the men through fear, the women love," he confided to his diary on June 13, 1849, en route to El Paso del Norte. "If an American is sick the females will watch beside his sick bed with as much earnest devotedness as a kind mother or sister could do. They appear to realize that the Americans are a superior race" (Weed 1849:37-38).

\section{CONCLUSION}

There were some striking contradictions in the Anglo depictions of the El Paso del Norte region. The town and its surrounding villages could not possibly have become such a large commercial entrepôt and thriving agricultural oasis if all of the Mexican men were the lazy, thieving, good-for-nothing gamblers that the Anglos thought them to be. Someone had constructed the churches and schools, the adobe houses and neighborhoods, the orchards and vineyards, the dams, and acequias. Someone was still maintaining the ditches, tilling the soil, picking the fruits and vegetables, harvesting the grapes, producing the wine, and distilling the "Pass whiskey." Surely all of this was not due solely to the labors of beautiful women with their "dark liquid eyes" and "fawn like figures."

Blinkered by their own prejudices, the Anglos all too often left the concept of hard work out of their calculations. They could see the handiwork, just not the hands behind it. From their perspective, the north bank of the river had been left underdeveloped because the Mexicans lacked the proper tools to transform its rocky soil into agricultural space and also because they lacked the proper firepower to control and defeat the Apaches. The south bank, meanwhile, was productive because of its naturally rich and well-watered soil and not because its landscape had been arduously improved upon, generation after generation, by laborers who had gradually turned a desert into an agricultural oasis.

In effect, the Anglo travelers insinuated a false passivity into the landscape (or, put differently, they "feminized" the landscape) in ways that reinforced their cultural prejudices: El Paso del Norte's soil was naturally bountiful, just as El Paso del Norte's women were naturally beautiful. The Mexicans were fortunate rather than productive, lazy rather than busy, lucky rather than plucky. In this sense, the Anglo soldiers and argonauts were merely replicating the same conquering mentality that had played itself out in the New World since the days of Columbus: justifying colonial expansion on the grounds that the local inhabitants were not fully utilizing the land; mistaking human-created landscapes for natural ones; and presuming that everything would improve once they were in charge of affairs.

Things did in fact begin to change once the Anglos gained a toehold at Ponce's Ranch (the future El Paso, Texas), just across the river from El Paso del Norte. But the changes did not occur at the pace, or in the manner, that the argonauts had so confidently foreseen. The burgeoning town never attracted the "hardy backwoodsman, with his axe on one shoulder" as Ruxton predicted (perhaps because deserts have so few trees!). But it did lure a lot of gamblers, drunks, murderers, thieves, desperadoes, misfits, con men, fringe 
characters, and ne'er-do-wells, whose behavior turned the argonauts' prejudice about Hispanics on its head. "Nobody worked," Owen White, one of El Paso's early pioneers and its first historian, wrote: "that is, nobody except Mexicans worked regularly. The 'white men' in the community did practically nothing for the very simple reason that there was nothing to do, and the very natural result of this pleasing state of affairs was that Uncle Ben Dowell's saloon sheltered the entire American male population of the town for the greater part of every day and for nearly all of every night" (White 1924:67).

Security remained a problem for decades as well. Military outposts came and went, as the U.S. Army struggled with the question of how best to secure its new southern frontier. First came the Post Opposite El Paso (better known as Coons' Ranch) from 1849-1851. Then came Fort Bliss at Magoffinsville (1854-1868), which was destroyed by a flood. The fort was moved to Concordia in 1868 and then disbanded in 1876 . Then, after the El Paso Salt War (1877-1878) revealed the deep underlying tensions between Anglos and Mexicans, the U.S. Army finally established a permanent military outpost in the city. The war with the Apaches also dragged on, belying the notion that Uncle Sam was any better at punishing (taking "his rod out of pickle" to use Eastland's colorful phrase) Native Americans than was the Mexican government. Small and large skirmishes continued in and around the El Paso del Norte region, on both sides of the border, for many more decades. Victorio and his forces held out until 1880, as did Geronimo and his forces until 1886.

In 1847, John Hughes foresaw the construction of a "turnpike, railroad or some other thoroughfare" to the El Paso del Norte region that would open up "a market for the fruits and wines of this river country." Instead, the Texas town of El Paso had to make do for nearly three decades with a handful of stagecoach companies, none of which were capable of delivering the region's produce and wine to the nation's dinner tables. And when the railroads finally did arrive in 1881, they did not turn the El Paso del Norte region into America's premier vineyard but instead paved the way for it to become a modest hay, alfalfa, and cottongrowing region and a major hub for the Mexican cattle trade. Meanwhile, the ever-increasing demand on the water resources of the Rio Grande upstream in Colorado and New Mexico, as well as the completion of Elephant Butte Dam in 1916, led to the dwindling of the fruit trees and vineyards on both sides of the river. By 1900, the self-sufficient "plantations" of yesteryear were giving way to mono-crop fields and an exportdriven agricultural market.

The racial divide also continued to grow, slowly but inexorably, as more and more Anglos settled in the region. El Paso incorporated as a city in 1873 and selected its first Anglo mayor, the saloon keeper Ben Dowell. A few years later, in 1883, it snatched the county seat from San Elizario in a fraudulent county election. The railroads, meanwhile, stimulated a population boom. Though Anglos would never outnumber ethnic Mexicans (except briefly in the 1890s), they exerted an influence on the fast-growing city far out of proportion to their numbers, imposing their vision of the area as an outpost of American civilization. "The City of El Paso is no longer a mere suburb [of El Paso del Norte]," the city business directory proudly proclaimed in 1885 (Rackliff \& Wainey 1885:2). In 1887, the El Paso Times devoted a special issue to the Anglo pioneers "whose efforts the present El Paso is indebted for commencing a work that has made the city what it is - an American community instead of one thoroughly Mexican" (El Paso Times 1887). And in 1923 the boosterish Gateway Club told its readers: "Our many Mexican-American citizens and our nearness to old Mexico solve the servant problem in El Paso. Mexican women and girls are inherently tidy and obliging and can easily be trained to become excellent household help. Domestic labor is abundant and inexpensive. A 
housemaid, a man to care for the garden or lawn, and similar help, may be hired for a small fraction of the wages paid this class of help elsewhere" (Gateway Club 1923).

None of these political, military, economic, and social transformations were inevitable. Yet all of them were clearly foreshadowed in the diaries and letters of the Anglos passing through El Paso del Norte in the late 1840s and early 1850s. First impressions had fateful consequences: the prejudiced stereotypes that they recorded in their travel accounts were premonitory of the racially divided society that El Paso would soon become-and long remain.

\section{REFERENCES CITED}

Anonymous

1977 Sketches from the Journal of a Traveler, Overland to California. In Southern Trails to California in 1849, edited by R. P. Bieber, pp. 259-280. Porcupine Press, Philadelphia.

Brockway, H. S.

1982 Across the Southern Trail to California. Private Press of John Cumming, Mount Pleasant, Michigan.

Comisión Internacional de Límites entre Mexico y los Estados Unidos.

1911 Memoria Documentada del Juicio de Arbitraje del Chamizal Celebrado en Virtud de la Convención de Junio 24 de 1910, Vol. 3. Talleres de Artes Gráficas, Mexico City.

Cox, C. C.

1849 Notes and Memoranda of an Overland Trip from Texas to California in the Year 1849. Unpublished manuscript, Huntington Library, San Marino, California.

Demarest, D. D.

1849-1850 Diary, March 8, 1849-May 1850, of a Trip in a Bark Norumbega to Galveston, Texas, then Overland to California. Unpublished manuscript, Bancroft Library, University of California, Berkeley.

Duval, I. H.

1987 Texas Argonauts: Isaac H. Duval and the California Gold Rush. Edited by R. H. Dillon. The Book Club of California, San Francisco.

Eastland, T. B. and Joseph G. Eastland

1939 To California Through Texas and Mexico: The Diary and Letters of Thomas B. Eastland and Joseph G. Eastland, His Son. California Historical Society Quarterly XVIII, no. 2:99-135.

Eccleston, R.

1950 Overland to California on the Southwestern Trail 1849: Diary of Robert Eccleston. Edited by G. P. Hammond and E. H. Howes. University of California Press, Berkeley and Los Angeles. 
Edwards, F. S.

1847 A Campaign in New Mexico with Colonel Doniphan. Carey and Hart, Philadephia.

Edwards, M. B.

1936 Marching with the Army of the West, 1846-1848. The Southwest Historical Series IV, edited by R. P. Bieber. Arthur H. Clark Co., Glendale, Calfornia.

E1 Paso County Historical Society

1859 Anson Mills, "Plat of El Paso." El Paso County Historical Society Archives, Burges House. El Paso, Texas.

El Paso Times

1887 "El Paso: The Gateway to Mexico! From an Adobe Village in 1881 to a Modern City in '87! The Crown Jewel of a New Commercial Empire." El Paso Times, Midsummer Trade Edition, August 1887:2. El Paso, Texas.

Emory, W. H.

1857-1859 Report on the United States and Mexican Boundary Survey, Vol. 1. Wendell, Washington, D.C.

Etter, P. A.

1998 To California on the Southern Route 1849: A History and Annotated Bibliography. Arthur H. Clark Co., Spokane, Washington.

García, M. T.

1981 Desert Immigrants: The Mexicans of E1 Paso, 1880-1920. Yale University Press, New Haven.

Gateway Club

1923 El Paso and the New Southwest. The Gateway Club, El Paso.

Gibson, G. R.

1974 Journal of a Soldier Under Kearny and Doniphan 1846-1847. The Southwest Historical Series III. Porcupine Press, Philadelphia.

Glasgow, E. J. and W. H. Glasgow

1993 Brothers on the Santa Fe and Chihuahua Trails: Edward James Glasgow and William Henry Glasgow, 1846-1848. Edited by Mark L. Gardner. University Press of Colorado, Boulder.

Gregg, J.

1844 Commerce of the Prairies, Vol. II. Henry G. Langley, New York.

Harris, B. B.

1960 The Gila Trail: The Texas Argonauts and the California Gold Rush. University of Oklahoma Press, Norman. 
Hughes, J. T.

1997 Doniphan's Expedition. Originally published in 1847. Texas A\&M University Press, College Station.

Kendall, G. W.

1935 Narrative of the Texan Santa Fé Expedition, The Steck Co., Austin.

Lagrange Company

1849 The Journal of the La Grange Company: Being the Record of a Journey from Texas to California in 1849. Unpublished manuscript, Stanford University Special Collections, Stanford, California.

Rackliff \& Wainey

1885 El Paso, Texas, and El Paso del Norte, Mexico, Business Directory for 1885. Published by Rackliff \& Wainey. Daily Journal Steam Printing House, Albuquerque.

Ramirez, Manuel Bernardo

2000 El Pasoans: Life and Society in Mexican El Paso, 1920-1945. Ph.D. dissertation, Department of History, University of Mississippi, Oxford.

Ruxton, G. F.

1916 Wild Life in the Rocky Mountains. The MacMillan Company, New York. Available online at http://www.xmission.com/ drudy/mtman/html/ruxton.html.

Sonnichsen, C. L.

1968 Pass of the North: Four Centuries on the Rio Grande, Vol. 1. Texas Western Press, El Paso.

Strentzel, L.

1983 A Letter from California, 1849. In Covered Wagon Women, Diaries and Letters from the Western Trails 1840-1890, Vol.1, edited by K. Holmes, pp. 247-269. Arthur H. Clark Co., Glendale, California.

Strickland, R.

1963 Six Who Came to El Paso, Southwestern Studies, no. 3. Texas Western Press, El Paso.

Timmons, T. W.

1990 El Paso: A Borderlands History. Texas Western Press, E1 Paso.

Weed, L. N.

1849 Narrative of a Journey to California in 1849. Unpublished manuscript, Beinecke Rare Book and Manuscript Library, Yale University, New Haven.

White, O.

1924 Out of the Desert: The Historical Romance of E1 Paso. McMath Co., El Paso. 
Whiting, W. H. C.

1938 Journal of a reconnaissance from San Antonio de Béxar to El Paso del Norte. In Exploring

Southern Trails 1846-1854, edited by R. P. Bieber, pp. 241-350. Arthur H. Clark Co., Glendale, California.

Wislizenus, F. A.

1848 A Tour to Northern Mexico, Connected with Col. Doniphan's Expedition, in 1846 and 1847. Tippin \& Streeper, Washington, D.C.

Woodhouse, S. W.

2007 From Texas to San Diego in 1851: The Overland Journal of Dr. S. W. Woodhouse, SurgeonNaturalist of the Sitgreaves Expedition. Edited by A. Wallace and R. H. Hevly. Texas Tech Press, Lubbock. 